\title{
Management Report Ex. Art. 2428 c.c. in Local Authority Companies
}

\author{
Nadia Oliva ${ }^{1}$ \\ ${ }^{1}$ University of Giustino Fortunato, Benevento, Italy \\ Correspodance: Nadia Oliva, University of Giustino Fortunato, Viale Delcogliano, 12 Benevento, Italy. Tel: \\ 39-328-465-0868. E-mail: n.oliva@unifortunato.eu
}

Received: September 29, 2015

Accepted: November 2, $2015 \quad$ Online Published: November 25, 2015

doi: 10.5539/ibr.v8n12p36

URL: http://dx.doi.org/10.5539/ibr.v8n12p36

\begin{abstract}
The aim of this paper is to analyze the Local Authorities management reports, particularly those of nine companies involved in the water distribution services in light of the changes made by the legislator to Article 2428 c.c. The new article of the Civil Code has, indeed, provided for the integration, in the management report, of a series of figures and prospective non-financial tools, regarding the environment, employees relationships and the company's performance, and provided information on developments of management, strategies, plans and business programs. The operational methodology used has been based on a detailed analysis of the existing literature on the matter and on an empirical analysis that has been actualized in the investigation of document sources (management reports and, where possible, social balance reports). What has emerged from the analysis is that, except that for few exceptions, there is a general lack of information on environment, risks and personnel. Indeed, through the recent changes and additions, the legislator has, in effect, made mandatory, albeit in an indirect (i.e. through the editing of the management report), the drafting of a mini social statement. This was necessary in light of the fact that the recent evolution of the role played by companies, and local authorities in particular, has led to the recognition of a social and environmental dimension of their activities, which combines and integrates with the management, economic, financial and competitive profiles.
\end{abstract}

Keywords: management report, local authorities, water distribution services

\section{Management Report: General Nature}

The Management Report, considered as a balance sheet integration, is edited by the administrators and supplies all information regarding the management trend, any possible corporate policies and strategies, economic and sectorial dynamics, information on costs, income and investments, development and research activities, the possible types of relationships with subsidiaries, associated companies, parent companies (Silvi, 2006, p. 13). The real peculiarity of the report is to give an overall view on the company's state and prospects, a "picture" able to push the information beyond quantitative data. The management Report, indeed, allows to go beyond some of the financial statement's informational limits. It's effective use makes it possible to translate the message emerging from the accounts into a language that is understandable to the less experienced readers ,2,3. In the past few years, on a Community and Standard Setter level of the main European and extra European countries, there has been a growing tendency, on the administrators' side, to insert in annual management reports a series of actual and context-related non-financial figures, such as environmental figures, employees relationships, and company performance together with information on forecasted management developments, on plans, strategies and corporate programs. At EU level, Directive n. 51/2003 of 17 July 2003 ha significantly modified art. 46 of the IV CEE Directive released on 25 July 1978 (which also regulates the content of the Management Report). One important subject discussed in the above mentioned more recent Directive concerns the information note to be supplied in the management Report. This document has been redrafted in light of the following considerations: it is required that the Report be an accurate account of the company's performance and that it describes the risks (financial risks, pricing risks, credit risks, liquidity risks and risks related to financial trends variations) and the uncertainties met during the management; furthermore, it requires some financial and non-financial indicators (ZANDA, 2007, p. 201). The information about management that are required today comply with the more recent communication standards pinpointed in business economics by literature, organizations, national and international procedures. Indeed, the group of data to be highlighted are in line with the Community's recommendations on environmental information notes, with the recommendations on the Green Book and the more recent guidelines on enterprises' social responsibility, with the international accounting standards, where 
required that the guideline be set by activity sectors, on risks, so as to realize a management report aimed to communicate the company's value, without overlooking any possibility for development and consequent risk areas (DE FRANCISCIS, 2007, p. 95). With publication in G.U. n. 73 of 28 march 2007 of lgs. D. N. 32/2007 the national legislature has acknowledged the said Directive. This work analyzes Local Authorities management reports, particularly those of nine companies involved in the water distribution services, in light of the changes made by the legislator to Article 2428 c.c. The new article of the Civil Code has, indeed, provided for the integration, in the management report, of a series of figures and prospective non-financial tools, regarding the environment, employees relationships and the company's performance, and provided information on developments on management, strategies, plans and business programs. The objective of this research is to verify whether or not and in which way the Campanian water service companies have adapted to the legislative evolution, given the importance of the social and environmental implications in a sector characterized by serious issues related to pollution and water shortage. The chosen theme examined here was determined by the consideration that water is a fundamental resource for the environment, the economy, the society, the peaceful cohabitation of people, in Italy and in the world. Water is a main component of existence, it represents the "sanctity of life" and it is therefore necessary that water be recognized as a human, undeniable right, and since it is a common good, it must also be considered a world heritage good. The population is increasing and the water supply is reducing. To date, one billion and three hundred millions people have no access to drinking water. It is therefore becoming strategic to control a supply that is running short compared to the growing demand. Today, therefore, the issue on water is taking a central role in the civic debate. Therefore, particular attention has been given to verifying whether or not, and in what terms, there is an ecological water production and distribution service transformation process in place. The operational methodology that has characterized this research has first of all provided a careful analysis of the existing literature through the retrieval of a bibliography on the subject of the management report and social reporting in public services distribution companies, dwelling particularly on the water supply services, that has acquired a notable relevance due to the importance held by water resources. Despite the difficulties encountered in gaining access to the examined companies' data, an empirical analysis was carried out ending with the analysis of documentary sources (management report and social balance, where present) and interviews with important stakeholders representatives of the Campania's water supply sector. The examination shows that, aside from very few exceptions, there is a total general absence of information regarding not only the environment, but also risks and personnel. In view of art. 2428 c.c. It would be desirable to give more space to such information in the future. It is necessary, for companies, to adopt a wide communication policy, widespread and clear, able to satisfy a growing demand for information regarding financial and competitive management results on one side, and social and environmental effects deriving from the activity on the other. The sustainability balance represents an evolution of the social balance, integrating the explanation of financial and social aspects with the environmental ones. The sustainability balance was originally created to give visibility to the social commitment of companies and to give an account of facts and circumstances that can be represented in the financial statement. Sustainability, however, is now progressively becoming a fundamental control and verification tool of the companies' policies in relation to the expectations of the different stakeholders categories, whether external or internal to the company.

\section{Conceptual Framework}

In accordance with Directive 2001/65/CE, art. 2428, which regulates the report's content, has been enhanced with an information note on financial and non-financial risks (personnel and environment).

\subsection{Information Note on Risks}

Art. 2428 has been enhanced with point 6-bis, aimed to require information on effects and possible impacts derived from the companies' use of financial tools. The definition of ever new financial tools and the evolution, in recent years, of the preexistent ones has allowed companies to develop new techniques to measure and face the risks related to such tools and to the "finance" function in general. In this context, the information relating to the company's exposure to the above mentioned risks, together with the policies implemented in order to face them, become of great importance to the recipients of accounting information. It is therefore imperative to define what situations can be held relevant to the users of balance sheets, taking into account the necessary reference parameter represented by the "evaluation of the financial and patrimonial situation". In this case, an exclusively quantitative approach does not seem to be the best feasible option. The administrators will have to entrust their critical appraisal in order to define, from time to time and based on each tangible particular case, when the efficiency of the financial instruments can be deemed significant under both a quantitative and a qualitative profile, by identifying with the expectations of balance sheet users and with their possible analysis. Such a molded evaluation will allow a best definition of the detailing degree of the information note to be supplied, also 
in relation to the different types of financial tools used, to the risks to be covered together with the volume of the transactions carried out. All of this is definitely moving toward an enhancement of the accountability systems4. For all cases which the regulation applies to, the code provides that the administrators describe:

- The company objectives and policies regarding financial risk management, including the hedging policy for each main category of expected transactions;

- The company's exposure to pricing risk, credit risk, liquidity risk and financial trends variations risk.

It is quite obvious that the aim of the legislator is to provide a complete disclosure on potential impacts of financial tools, on the financial and patrimonial situation, on the financial results as well as on the financial trends expected by the company (OIC, 2006, p. 27). The qualitative and quantitative information on risks must be provided by the company "in relation to the company's use of financial tools and whether they are relevant to the evaluation of the patrimonial and financial situation and to the economic result for the financial year" (Caratozzolo, 2006, p. 1029). Regarding the specific information on financial risk exposure, the risks to be considered are credit risks, pricing risks, liquidity risks and financial trends variations risks. Regarding the above mentioned risks, the information to be provided could be a concise qualitative reporting of the risk management objectives and policies and of the hedging operations carried out, while for the credit risk exposure it could be the maximum exposure amount (unless shown in the balance sheet), a description of the guarantees and a classification of overdue amounts ordered by age (oldest overdue amount first); for the liquidity risk it could be a classification of payment obligations ordered by due date, with a brief indication of the resources that will be used to meet such obligations. For the market risks exposure it is not required to make a sensitivity analysis, which can be substituted by qualitative indications, despite such indications must be provided for each type of market risk.

\subsection{Non-Accounting Information Note}

For about a decade in our country we have been watching a great awareness phenomena raising toward social issues. This phenomena is included in a radical change happening in the welfare system and concept itself, which is radically affecting the traditional roles assigned to "private", "public" and "third sector". In this new environmental context the actors of each sector recognize the importance of the ability to use scarce resources to create a real "value added" to benefit the Community, and are frequently adopting ad hoc tools to communicate their social performance. The institutionalization of the social reporting practices is confirmed by both the development of aimed professional services (consulting, training, certification) and regulatory initiatives which tend to make it mandatory (Oliva, 2008, pp. 59-64). L.D. 118/2005, for example, requires social enterprises, (being them social cooperatives, associations, foundations), to draw up a social balance to be attached to the year's financial statement. Similarly, in the public administration sector, the Directive on the Public Functions Office of 16 march 2006, offers some guidelines for social reporting. Lastly, the guidelines for social reporting for local authorities issued by the Home Office. The non-accounting reporting, and social reporting in particular, aims to achieve the following goals: To provide all stakeholders with an overall picture of the company's performance; to provide useful information on the quality of the company's activity in order to extend and improve, also under a social/ethical profile, the knowledge and the possibility of evaluation and choice of all stakeholders.

\subsection{Information Note on Personnel}

The usual success factors for a company, such as product and process technology, protected and regulated markets, access to financial resources and economies of scale may still be competitive tools, but company culture and organizational abilities, which derive from the way in which people are managed, must coherently become constant features. The human factor is by nature a production factor full of potentialities which are sometimes used and sometimes neglected by companies. When the production process starts, every production factor is fully used in its integrity; however, the human factor is not always used at its best and sometimes, individuals' knowledge and abilities, which, in the right conditions could be offered to the company, are often neglected (Ricci, 2007, p. 73). Human labor, for its intrinsic properties, shows some extra-economic aspects of a moral nature which cannot be ignored. Economics, as well as ethics, demand that the moral human aspect be considered when there are work problems, if only for the lowering of the performance level deriving from neglecting them, which resolves in indirect damage which will in turn deflate the complex efficiency and cost effectiveness of the companies. (Onida, 2005, p. 138). Human resources, therefore, represent one of the most important competitive advantage sources for companies. For this reason, we must not be surprised if the legislator has provided that information on personnel be included in the management report. (new art. 2428, par. 2, c.c.). Some of the most relevant information to be included in management Reports are those relating to work 
sites conditions. To protect work conditions means to take care of every functional aspect of the labor legislation and to ensure employees health, safety and dignity. Every employee's health and safety in every workplace is a fundamental and actual objective, and it can be pursued by searching for better and greater occupation in this transformed job market, granting work its essential peculiarity of being a circumstance for individuals' fulfillment of their human dignity5 (e.g. provisions as per art. 1 and 4 of the Italian Constitution Act). Such aim, in accordance with Community guidelines, requires that companies support work quality and safety for every employee. Some most relevant personnel information are those relating to education and refresher training. Information on average employee seniority are also quite relevant. In this respect, a reduction in company's seniority may take on a positive meaning should this be an expression of a policy meant to hire young workforce coming from different contexts in order to facilitate strategy renovation. Furthermore, a brief description of employment relationships, with special attention to the relevant contents of contracts renewals and union relationships is essential. Such indication may usefully be supported by working hours data reports, absenteeism data, overtime effect, strike hours. The latter, for example, when compared to total working hours, allows a calculation of the company's conflict rate (Molteni, 2000, p. 148). Another crucial aspect is the promotion of equal opportunities between men and women at work. One of the main obstacles women face when entering the job market, is the possibility to balance work and family life, regardless of education and employment situation. In modern companies it is becoming more and more important to define career paths that are as clear as possible. It is imperative to inform all the stakeholders regarding these matters. For what concerns information regarding remuneration systems and incentive policies, it is to be noted that frequently, in modern enterprises, the work organization tends to promote an active human and economic integration of employees in the company, by giving space to collaborative relationships and bonds of solidarity which entail employee participation to the results of the enterprise as a common good. In this framework we can fit some forms of work remuneration (or better, some forms of integration of such remuneration): Integration linked to the production volume or to the "value added" or to the net income for the year. However, profit sharing may raise the spirit of solidarity and cooperation amongst the employees on one side, since everyone's actions contribute to the final result, but it also may discourage the effort of the individual employee on another side, being there a possibility that one's diligence might be neutralized by another's negligence. Rather than as an input to encourage a better work performance or to improve the employees financial situation, profit sharing might be used for its psychological, moral and educational value, since it connects work to capital by creating a common interest in the final year results, it accustoms any degree of personnel to follow the company's general financial trend, it supports employees growth toward ample and responsible cooperation and affirms the concept of the workers' community being not a passive instrument, but an active and responsible subject, together with the management personnel of the company's production (Onida, 2005, p. 220). All of these indications are very topical nowadays. In summary, the information to be provided could be:

- $\quad$ Educational and professional refresh training activities that were planned and carried out;

- $\quad$ Chosen remuneration policies and career systems adopted;

- $\quad$ Initiatives meant to promote equal opportunities;

- $\quad$ Creation of crèche facilities;

- Workplace conditions;

- Activities meant to generally promote the role of human resources within the company.

\subsection{Information Note on Environment}

Environmental quality is to be considered as an essential feature of the quality of life in a society and therefore as an essential feature of economic development conditions. The need to pursue a sustainable development is determining some deep changes in public policies; it is now imperative for enterprises to conceive and manage the environmental variable in a completely new perspective. As sustainable development is not something that comes automatically and spontaneously, there is a need for enterprises to adopt appropriate public policies in order to promote specific investments in environmental technologies so as to reduce their environmental impact. The growing attention of public opinion and governments toward environmental issues linked to production activities has brought companies to create communication tools that are purely environmental. Starting from 1990 there has been an increase in the number of companies that submit environmental reports to their annual board meetings for financial statement approval (Terzani, 2000, p. 263). Some of the environmental indicators to be considered could be: Environmental performance indicators, that express qualitative and quantitative values able to evaluate the use of resources both under an efficiency and an effectiveness profile; environmental impact indicators, that measure the effect of the company's activity on the environment; environmental performance 
indicators, that evaluate the environmental efficiency by releasing it from the fluctuations of the production levels; potential effect indicators, that give an evaluation of the effect that the company's activity could have on the environment; environmental effect indicators, that evaluate the actual environmental variations due to the company's activity.

More indicators are being classified and standardized such as Regulation ISO 14031 or the Global Reporting Initiative method. Environmental information may be divided in two main categories linked to the company's size and they refer to: Site or location environmental reporting, when the information and the data refer to individual plants or production factories; corporate environmental reporting when the information and the data refer to a multi-site enterprise (Metallo et al., 2005, p. 162). Environmental reporting is meant for stakeholders, who, by prevailing doctrine, can be divided, in: Politicians (national and international legislators); internal audience (management, employees, shareholders); market (competitors, customers, suppliers, consumers organizations); financial and public subjects (local population, environmental organizations, workers unions, mass media, scientific institutions, insurance companies and banks). Mostly large companies, nowadays, provide environmental reports and they mostly have background origins in the chemical, pharmaceutical and oil sectors, where the production processes may have a greater environmental impact, but lately, a growing interest is moving in this direction companies belonging to the service and manufacturing sectors (Ranghieri et al., 1997). Almost all environmental reports contain information extrapolated from environmental performance indicators, with special attention to gas consumption and emissions, to productions, to processed raw materials and conveyed materials. They also contain quantitative and financial data, like, for example, environmental expenses, divided in current expenses and investments, or the costs incurred for employees health and safety. Environmental information may be contained in the management report and it is obtained through the drawing of quantitative charts meant to sum up physical and financial environmental management data which, noted in special accounts, are later re-elaborated with the aim of evaluating efficiency and effectiveness of the company's sustainable orientation. The legislative provision will allow the pursuit of some benefits deriving from the monitoring of significant environmental aspects. They are easily recognizable in: identification of environmental costs and waste; evaluation of opportunities for investments in environmental friendly technologies; evaluation of the level of care taken in territory development, identification of critical elements linked to one's own activity and of the action meant for environmental improvement; creation of a monitoring network that allows an environmental management system development (ISO14000 od EMAS); development of efficient environmental communication tools for the population and public administration. Attention should be paid to the company's reputation benefits (therefore to its value) which stem from a better fulfillment of the stakeholders' cognitive needs (including an increased trust in banks, in public administration offices, in insurance companies) and from a tangible demonstration of a greater commitment in the management of environmental issues.

\section{Methodology}

The operational methodology used has been based on a detailed analysis of the existing literature on the matter and on an empirical analysis that has been actualized in the analysis of document sources (management report and, where possible, social balance reports), found through company sites or CCIAA archives. From the study of the literature of the Italian water services it appears evident that for the whole of the XX century, the public sector role remained largely dominant. In fact in the late 80 s the private sector was managing no more than the $4.5 \%$ of the entire sector (Giuntini, 2000, p. 15). Historically, property and management of urban water service in Italy have been characterized by the same tendencies as other European countries, based on municipal policies dating back to the XIX century. In 1880 the first Italian Municipal Enterprises (today called Aziende municipalizzate), where established, and they were in charge of the water distribution service management in the great majority of the Italian provinces. Furthermore, the geographical distribution of the water distribution companies and their dimensions cannot be connected to the Italian history, characterized by a late establishment of the national state and by a strong political and administrative localism. The Italian territory has been historically characterized by political cultures, extremely different degrees of economic development and geographical contexts (Conti, 2000, pp. 201-216). Hence the typical fragmentary nature of the Italian water industry. The consequences of this framework are still visible in the Italian water distribution system and are the reason of the high level of disparity between Northern Italy and Southern Italy in terms of service quality. Several changes have happened in the water distribution service in Italy during the past decades. Regulation $\mathrm{n}$. 36 of 1994, also known as Galli Regulation, in addition to open up to the sector's liberalization, has provided for the creation of the ATOs (Optimul Territorial Context), which are territorial offices in charge of the water distribution system in its whole. However, the importance of the Galli Regulation goes beyond the management of the services. It has, in fact, set forth some very important principles: That water is a public property to be 
safeguarded and used according to solidarity criteria, that it must be protected in order to guarantee the right to its use to the new generations and for the first time it has set human consumption of water as primary compared to other uses (in agriculture, in industry, etc) (Bazzani, 2003). Let's now examine the management Report of nine water distribution companies in Campania:

- $\quad$ Alto Calore Servizi S.p.A.7;

- $\quad$ Ausino S.p.A.8;

- $\quad$ Arin S.p.A.9;

- $\quad$ ASIS S.p.A.10;

- $\quad$ Consac Gestioni Idriche S.p.A.11;

- $\quad$ Energia Verde Idrica (EVI) S.p.A.12;

- $\quad$ GORI S.p.A.13;

- $\quad$ Gesesa S.p.A.144;

- $\quad$ Salerno Sistemi S.p.A 15.

The main information has been highlighted in special tables 16 defining the main information on each company's management report. In particular were considered research and development activities, relationships with subsidiaries and/or parent companies, important facts taking place after year end closing and possible evolution of management and information on financial risks, environment and personnel. Such investigation has taken place considering the documents produced during year 2013, except that for Salerno Sistemi, for which year 2012 was considered, since the management report for year 2013 was not drawn.

\section{Results}

At the end of the research job, it emerged that, except that for few exceptions, there is a general lack of information on environment, risk and personnel. Today there is a general interest manifesting non only as a sum of the expectations of individuals who entertain direct relationships with the company, but also as an interest of the community. Indeed, the water distribution sector in Campania, together with the waste management sector, is the one with the worst infrastructural deficiencies, administrative backwardness and weaknesses of the qualitative/quantitative standard performances. These services more than others would need to be totally renewed. This should suggest to not take the water distribution sector away from the transformation process so as to not hinder its industrial development, which in many cases has already been started and realized, avoiding to confine it within local and public limits. This transformation process will have to happen in the consciousness that even an unrestrained privatization process of this sector could lead to considerable risks: privatization, indeed, could lead to an increase in fares, a deterioration of the water quality, and a general worsening of the standards of service. It would be desirable that these companies become aware of the fact that they offer an essential public service and that they decide to start and develop a continuous improvement process of the company's methods aimed to: Improve the quality of the product/service offered and the customers' satisfaction, that is the physical, chemical, microbiological and organoleptic property of the water supplied, in accordance with the provisions set out by law; improve the quality of the customer relationships, guaranteeing: prompt and complete response to customers complaints; completeness and effectiveness of the information; reliability and punctuality of the collection and billing of the usage data; efficiency and effectiveness of the access to the service; to meet the commitment toward the Service Chart; to reduce the costs of company's management.

\section{Final Considerations}

The research project that has been carried out has contributed to increase knowledge and to offer important innovational inputs regarding the management report in the public sector. From the writings emerge the structural rigidities of water supply companies in Campania, such as the antiquated plant design caused by the persistent lack of investments that do not allow renovation of the plants that have completed their life cycle, the inadequate technology innovation, the presence, in some territories, of a high number of users that are active only a few days a year. These represent disadvantage points which reflect negatively on the management of the company. The water distribution service sector has always been considered as some sort of grey area far from political disputes and from streamlining possibilities and this has, in many cases, produced a scarce attention toward social, economic and environmental relevance of the activities involved in it. The water sector opposition to progress on environmental issues related to the management of a resource such as water has been proved by the slow, difficult and incomplete adjustment to the instructions set out by law. The need for a more rational and sustainable management has involved companies in the improvement of their economic performances more than 
their environmental performance. In order to modernize and improve the service, the subjects involved in the distribution of water supply services should simplify the rigid organizational structure, dismantle the highly centered bureaucratic system that is peculiar to public companies and set out a management method based on actual entrepreneurial perspectives, with expert managers, and a meritocratic system up for a real participation of the company itself to the improvement process. Particularly, for some of them there was a request to fill in a questionnaire aimed to better understand the peculiarity of the companies examined. Furthermore, the recent evolution of the role played by companies has entailed recognition of a social and environmental dimension in their activity, which stands side by side and integrates with the management's financial, economic and competitive profiles. Indeed, the community intensely expresses needs and expectations that affect the growth of the organizational system, the concept itself of development and its sustainability, growth and development which must be compatible with needs and expectations expressed by the community. The growing knowledge of the role that companies play in the environmental and social fields has justified the interest of the legislator toward social communication intended as creation of a shared value. For this purpose, it was useful to create a base model for the drafting of the management report which the administrators can refer to in their final recap job. This form was set out as an example to which elements taking into account the nature of each individual company 16 must be added. In the light of the new art. 2428 c.c. it appears clear that the management Report is increasingly being set up as an actual social balance. The legislator, indeed, has provided for the integration, in the management report, of a series of information, such as those relating to environment and personnel, that where an exclusive scope of the social balance, which is a document that, unlike the management report, limited companies are not yet required to submit together with the financial statement. In fact, through recent modifications and integrations operated on art. 2428 c.c., the legislator has made mandatory, however indirectly (meaning through the drafting of the management report), the editing of a mini social balance The implementation of an yearly sustainability balance might contribute to produce a series of important results: a growing personnel involvement in the company's activities and a development of the sense of belonging, an improvement of the process of information and data gathering to be published so as to increase the company's reputation and visibility toward the community; a strengthening of the dialogue with some stakeholders categories, a growing awareness regarding social responsibility and enterprise responsibility; a greater attention toward water saving.

Table 1. General information on the companies examined

\begin{tabular}{|c|c|c|c|c|c|c|c|c|c|}
\hline & $\begin{array}{c}\text { ALTO } \\
\text { CALORE }\end{array}$ & GE.SE.SA & $\mathrm{ABC}$ & EVI & AUSINO & $\begin{array}{c}\text { CONSAC } \\
\text { G.I. }\end{array}$ & GORI & $\begin{array}{c}\text { SALERNO } \\
\text { SISTEMI }\end{array}$ & ASIS \\
\hline Legal Form & S.p.A. & S.p.A. & $\begin{array}{l}\text { Azienda } \\
\text { Speciale }\end{array}$ & S.p.A. & S.p.A. & S.p.A. & S.p.A. & S.p.A. & S.p.A. \\
\hline Share Capital & 27.158 .873 & 520.632 & 53.373 .044 & 400.000 & 886.689 & 9.387 .351 & 44.999 .971 & 120.000 & 3.807 .100 \\
\hline $\begin{array}{l}\text { Registered } \\
\text { office }\end{array}$ & Avellino & Benevento & Napoli & Ischia & $\begin{array}{c}\text { Cava } \\
\text { De'Tirreni }\end{array}$ & $\begin{array}{l}\text { Vallo Della } \\
\text { Lucania }\end{array}$ & Ercolano & Salerno & Salerno \\
\hline Provinces served & $\begin{array}{l}\text { Avellino } \\
\text { Benevento }\end{array}$ & Benevento & Napoli & Napoli & Salerno & Salerno & Salerno/Napoli & Salerno & Salerno \\
\hline $\begin{array}{c}\text { Municipalities } \\
\text { served }\end{array}$ & 125 & 13 & 136 & 6 & 34 & 53 & 76 & 6 & 50 \\
\hline $\begin{array}{l}\text { Number of } \\
\text { employees }\end{array}$ & 359 & 48 & 403 & 76 & 56 & 90 & 667 & 123 & 90 \\
\hline Year results & -5.266 .772 & 30.409 & 1.373 .000 & 64.362 & 50.010 & 42.747 & -189.732 & 62.731 & 18.036 \\
\hline
\end{tabular}


Table 2. Management report for Alto Calore S.P.A. (year 2013): content

\begin{tabular}{|c|c|c|c|c|c|c|}
\hline $\begin{array}{c}\text { Research and } \\
\text { development } \\
\text { activities }\end{array}$ & $\begin{array}{l}\text { Relationships with } \\
\text { subsidiaries, } \\
\text { associated } \\
\text { companies, parent } \\
\text { companies and } \\
\text { companies controlled } \\
\text { by them } \\
\end{array}$ & $\begin{array}{c}\text { Significant events } \\
\text { occurred after year end } \\
\text { closing }\end{array}$ & Business Outlook & $\begin{array}{l}\text { Information } \\
\text { on company } \\
\text { management } \\
\text { and financial } \\
\text { risks }\end{array}$ & $\begin{array}{l}\text { Information } \\
\text { on the } \\
\text { Environment }\end{array}$ & $\begin{array}{c}\text { Information } \\
\text { on } \\
\text { Personnel }\end{array}$ \\
\hline- & - & $\begin{array}{l}\text { In } 2014 \text { an important } \\
\text { settlement agreement was } \\
\text { reached; together with the } \\
\text { counterparties attorney, it } \\
\text { was possible to quantify } \\
\text { discounts and payment } \\
\text { plans referring to disputes } \\
\text { regarding expropriation } \\
\text { and occupation costs. }\end{array}$ & $\begin{array}{l}\text { The Management Board has } \\
\text { undertaken a number of } \\
\text { activities aimed to make the } \\
\text { company's management } \\
\text { more efficient. It is planned } \\
\text { to reduce electricity and } \\
\text { personnel costs through a } \\
\text { restraint on expenses } \\
\text { relating to overtime work. }\end{array}$ & - & - & \\
\hline
\end{tabular}

Table 3. Management report for Ge.Se.Sa. S.P.A. (year 2013): contents

\begin{tabular}{|c|c|c|c|c|c|c|}
\hline $\begin{array}{c}\text { Research and } \\
\text { development } \\
\text { activities }\end{array}$ & $\begin{array}{c}\text { Relationships with } \\
\text { subsidiaries, associated } \\
\text { companies, parent } \\
\text { companies and } \\
\text { companies controlled } \\
\text { by them }\end{array}$ & $\begin{array}{c}\text { Significant } \\
\text { events occurred } \\
\text { after year end } \\
\text { closing }\end{array}$ & Business Outlook & $\begin{array}{l}\text { Information on } \\
\text { company } \\
\text { management and } \\
\text { financial risks }\end{array}$ & $\begin{array}{l}\text { Information } \\
\text { on the } \\
\text { Environment }\end{array}$ & $\begin{array}{l}\text { Information } \\
\text { on Personnel }\end{array}$ \\
\hline $\begin{array}{l}\text { There were } \\
\text { no research } \\
\text { and } \\
\text { developme } \\
\text { nt activities } \\
\text { in the year. }\end{array}$ & $\begin{array}{l}\text { The relationships } \\
\text { with the parent } \\
\text { company are } \\
\text { regulated by specific } \\
\text { contracts that } \\
\text { concern special } \\
\text { services provided by } \\
\text { ACEA s.p.a. to } \\
\text { Ge.se.sa relating to } \\
\text { organizational } \\
\text { activities, } \\
\text { accounting } \\
\text { consulting and } \\
\text { financial control, for } \\
\text { the two-year period } \\
2011-2013\end{array}$ & $\begin{array}{l}\text { Significant events } \\
\text { occurred after } \\
31.12 .2013 \\
\text { concern provisions } \\
\text { through which the } \\
\text { authority has } \\
\text { approved the } \\
\text { billing method for } \\
\text { water distribution } \\
\text { services (MTI) for } \\
\text { the years } \\
\text { 2014-2015, in } \\
\text { order to complete } \\
\text { the first regulating } \\
\text { period referring to } \\
\text { years 2012-2015 }\end{array}$ & $\begin{array}{l}\text { With L. D. 201/2011 } \\
\text { converted into L. } 214 / 2011 \text {, } \\
\text { the Authority for electricity } \\
\text { and gas was given } \\
\text { jurisdiction on water } \\
\text { distribution services as well. } \\
\text { Particularly, the authority was } \\
\text { given control on all } \\
\text { regulation and definition of } \\
\text { the billing system and on the } \\
\text { quality of service provided. } \\
\text { Some uncertainties persist, } \\
\text { however, on the situations for } \\
\text { which there is not yet an } \\
\text { appointed manager for the } \\
\text { provinces of Benevento and } \\
\text { Avellino. }\end{array}$ & $\begin{array}{l}\text { The risk fund has been } \\
\text { operated during the } \\
\text { course of } 2013 \text { due to } \\
\text { the use of the accrued } \\
\text { amount to cover the } \\
\text { risk related to } \\
\text { recognition of the } \\
\text { sewage maintenance } \\
\text { fee by the City Council } \\
\text { of Benevento. In } 2013 \\
\text { the company paid the } \\
\text { installments of the } \\
\text { mortgage taken out in } \\
2010 \text { for the renovation } \\
\text { of its headquarters to } \\
\text { the Banca della } \\
\text { Campania. }\end{array}$ & $\begin{array}{l} \\
(1 \\
\\
\\
\\
\\
\end{array}$ & $\begin{array}{c}\text { Personnel } \\
\text { costs have } \\
\text { been reduced } \\
\text { by } 1.5 \% \\
\text { thanks to a } \\
\text { reduction in } \\
\text { holiday/perm } \\
\text { its/overtime } \\
\text { costs. }\end{array}$ \\
\hline
\end{tabular}


Table 4. Management report for Ausino S.P.A. (year 2013): contents

\begin{tabular}{|c|c|c|c|c|c|c|}
\hline $\begin{array}{c}\text { Research and development } \\
\text { activities }\end{array}$ & $\begin{array}{c}\text { Relationships with } \\
\text { subsidiaries, associated } \\
\text { companies, parent } \\
\text { companies and } \\
\text { companies controlled } \\
\text { by them }\end{array}$ & $\begin{array}{l}\text { Significant events } \\
\text { occurred after } \\
\text { year end closing }\end{array}$ & $\begin{array}{l}\text { Business } \\
\text { Outlook }\end{array}$ & $\begin{array}{l}\text { Information on } \\
\text { company management } \\
\text { and financial risks }\end{array}$ & $\begin{array}{l}\text { Information } \\
\text { on the } \\
\text { Environment }\end{array}$ & $\begin{array}{l}\text { Information } \\
\text { on Personnel }\end{array}$ \\
\hline $\begin{array}{l}\text { The company is carrying } \\
\text { out two important research } \\
\text { projects: "Watergrid", and } \\
\text { "Aquasystem". } \\
\text { The first one started in } \\
2011 \text { and it is meant to } \\
\text { validate the innovative } \\
\text { technologies and processes } \\
\text { aimed to the } \\
\text { districtualization of the } \\
\text { urban water distribution } \\
\text { networks. } \\
\text { The second project started } \\
\text { in } 2012 \text { and it is meant to } \\
\text { find innovative processes } \\
\text { and technologies for an } \\
\text { integrated and planned } \\
\text { management of water } \\
\text { supplies, the cost effective } \\
\text { energy optimization and the } \\
\text { quality control in the } \\
\text { integrated water cycle. } \\
\text { Both projects are sponsored } \\
\text { by MIUR. }\end{array}$ & $\begin{array}{l}\text { ABC Azienda speciale } \\
\text { is wholly owned by the } \\
\text { City Council of Naples, } \\
\text { which operates its } \\
\text { activity, coordination } \\
\text { and management. The } \\
\text { company retains full } \\
\text { controlling investment } \\
\text { in Net Service S.r.l., } \\
\text { which suffered a } \\
\text { business loss. } \\
\text { For this reason, the } \\
\text { company is evaluating } \\
\text { the possibility to merge } \\
\text { with this subsidiary } \\
100 \% \text {, in agreement } \\
\text { with the authority that } \\
\text { owns it. ABC owns } \\
\text { controlling investment } \\
\text { for } 70 \% \text { directly and for } \\
30 \% \text { indirectly through } \\
\text { Net Service, of } \\
\text { Consorzio Serino. }\end{array}$ & $\begin{array}{l}\text { In early } 2014 \text { the } \\
\text { company } \\
\text { evaluated the } \\
\text { possibility to fully } \\
\text { merge with its } \\
\text { subsidiary Net } \\
\text { Service s.r.l., that } \\
\text { should carry out a } \\
\text { similar operation } \\
\text { with its own } \\
\text { subsidiary Marino } \\
\text { Lavori S.r.l. } \\
\text { Furthermore, the } \\
\text { City Council of } \\
\text { Naples is planning } \\
\text { the closing of } \\
\text { Consorzio San } \\
\text { Giovanni, whose } \\
\text { resources should } \\
\text { migrate to the } \\
\text { company next } \\
\text { September. }\end{array}$ & $\begin{array}{l}\text { On the } \\
\text { financial side, } \\
\text { the situation in } \\
\text { the first six } \\
\text { months of } \\
2014 \text { seems to } \\
\text { be better } \\
\text { compared to } \\
\text { the forecast, } \\
\text { thanks to a } \\
\text { good credit } \\
\text { collection } \\
\text { trend both } \\
\text { from private } \\
\text { and public } \\
\text { customers. }\end{array}$ & $\begin{array}{l}\text { As the company } \\
\text { became a joint stock } \\
\text { company (S.p.a.), its } \\
\text { social security } \\
\text { management passed on } \\
\text { to INPS and INPDAP. } \\
\text { The company is } \\
\text { working to make sure } \\
\text { that the expensive } \\
\text { contributions merging } \\
\text { will not cause any } \\
\text { damage to its } \\
\text { employees. At last, the } \\
\text { company has received } \\
\text { two tax assessment } \\
\text { notices from the } \\
\text { Inland Revenue } \\
\text { (Agenzia delle } \\
\text { Entrate) that are } \\
\text { currently being } \\
\text { disputed. }\end{array}$ & $\begin{array}{l}\text { The company } \\
\text { has all the } \\
\text { environmental } \\
\text { aspects } \\
\text { related to its } \\
\text { activity under } \\
\text { control and } \\
\text { has achieved } \\
\text { the ISO } \\
14001 \\
\text { standard. }\end{array}$ & $\begin{array}{c}\text { The company } \\
\text { has obtained } \\
\text { the OHSAS } \\
18001: 2007 \\
\text { certification } \\
\text { thanks to its } \\
\text { health and } \\
\text { safety } \\
\text { management } \\
\text { system. }\end{array}$ \\
\hline
\end{tabular}

Table 5. Management report for Abc Azienda Speciale (year 2013): contents

\begin{tabular}{|c|c|c|c|c|c|c|}
\hline $\begin{array}{c}\text { Research and development } \\
\text { activities }\end{array}$ & $\begin{array}{c}\text { Relationships with } \\
\text { subsidiaries, associated } \\
\text { companies, parent } \\
\text { companies and companies } \\
\text { controlled by them }\end{array}$ & $\begin{array}{l}\text { Significant events } \\
\text { occurred after year } \\
\text { end closing }\end{array}$ & $\begin{array}{l}\text { Business } \\
\text { Outlook }\end{array}$ & $\begin{array}{c}\text { Information on } \\
\text { company management } \\
\text { and financial risks }\end{array}$ & $\begin{array}{l}\text { Information } \\
\text { on the } \\
\text { Environment }\end{array}$ & $\begin{array}{l}\text { Information } \\
\text { on Personnel }\end{array}$ \\
\hline $\begin{array}{l}\text { The company is carrying out } \\
\text { two important research } \\
\text { projects: "Watergrid", and } \\
\text { "Aquasystem". } \\
\text { The first one started in } 2011 \\
\text { and it is meant to validate the } \\
\text { innovative technologies and } \\
\text { processes aimed to the } \\
\text { districtualization of the urban } \\
\text { water distribution networks. } \\
\text { The second project started in } \\
2012 \text { and it is meant to find } \\
\text { innovative processes and } \\
\text { technologies for an integrated } \\
\text { and planned management of } \\
\text { water supplies, the cost } \\
\text { effective energy optimization } \\
\text { and the quality control in the } \\
\text { integrated water cycle. Both } \\
\text { projects are sponsored by } \\
\text { MIUR. }\end{array}$ & $\begin{array}{l}\text { ABC Azienda speciale is } \\
\text { wholly owned by the City } \\
\text { Council of Naples, which } \\
\text { operates its activity, } \\
\text { coordination and } \\
\text { management. The } \\
\text { company retains full } \\
\text { controlling investment in } \\
\text { Net Service S.r.l., which } \\
\text { suffered a business loss. } \\
\text { For this reason, the } \\
\text { company is evaluating the } \\
\text { possibility to merge with } \\
\text { this subsidiary } 100 \%, \text { in } \\
\text { agreement with the } \\
\text { authority that owns it. } \\
\text { ABC owns controlling } \\
\text { investment for } 70 \% \\
\text { directly and for } 30 \% \\
\text { indirectly through Net } \\
\text { Service, of Consorzio } \\
\text { Serino. }\end{array}$ & $\begin{array}{l}\text { In early } 2014 \text { the } \\
\text { company evaluated } \\
\text { the possibility to } \\
\text { fully merge with its } \\
\text { subsidiary Net } \\
\text { Service s.r.l., that } \\
\text { should carry out a } \\
\text { similar operation } \\
\text { with its own } \\
\text { subsidiary Marino } \\
\text { Lavori S.r.l. } \\
\text { Furthermore, the } \\
\text { City Council of } \\
\text { Naples is planning } \\
\text { the closing of } \\
\text { Consorzio San } \\
\text { Giovanni, whose } \\
\text { resources should } \\
\text { migrate to the } \\
\text { company next } \\
\text { September. }\end{array}$ & $\begin{array}{l}\text { On the } \\
\text { financial } \\
\text { side, the } \\
\text { situation } \\
\text { in the first } \\
\text { six } \\
\text { months of } \\
2014 \\
\text { seems to } \\
\text { be better } \\
\text { compared } \\
\text { to the } \\
\text { forecast, } \\
\text { thanks to a } \\
\text { good } \\
\text { credit } \\
\text { collection } \\
\text { trend both } \\
\text { from } \\
\text { private } \\
\text { and public } \\
\text { customers. }\end{array}$ & $\begin{array}{l}\text { As the company } \\
\text { became a joint stock } \\
\text { company (S.p.a.), its } \\
\text { social security } \\
\text { management passed } \\
\text { on to INPS and } \\
\text { INPDAP. The } \\
\text { company is working } \\
\text { to make sure that the } \\
\text { expensive } \\
\text { contributions merging } \\
\text { will not cause any } \\
\text { damage to its } \\
\text { employees. At last, the } \\
\text { company has received } \\
\text { two tax assessment } \\
\text { notices from the } \\
\text { Inland Revenue } \\
\text { (Agenzia delle } \\
\text { Entrate) that are } \\
\text { currently being } \\
\text { disputed. }\end{array}$ & $\begin{array}{l}\text { The company } \\
\text { has all the } \\
\text { environmental } \\
\text { aspects } \\
\text { related to its } \\
\text { activity under } \\
\text { control and } \\
\text { has achieved } \\
\text { the ISO } \\
14001 \\
\text { standard. }\end{array}$ & $\begin{array}{l}\text { The company } \\
\text { has obtained } \\
\text { the OHSAS } \\
\text { 18001:2007 } \\
\text { certification } \\
\text { thanks to its } \\
\text { health and } \\
\text { safety } \\
\text { management } \\
\text { system. }\end{array}$ \\
\hline
\end{tabular}


Table 6. Management report for Salerno Sistemi S.P.A. (year 2012): contents

\begin{tabular}{|c|c|c|c|c|c|c|}
\hline $\begin{array}{c}\text { Research and } \\
\text { development activities }\end{array}$ & $\begin{array}{l}\text { Relationships with } \\
\text { subsidiaries, associated } \\
\text { companies, parent } \\
\text { companies and } \\
\text { companies controlled } \\
\text { by them }\end{array}$ & $\begin{array}{c}\text { Significant } \\
\text { events occurred } \\
\text { after year end } \\
\text { closing }\end{array}$ & Business Outlook & $\begin{array}{l}\text { Information on } \\
\text { company } \\
\text { management and } \\
\text { financial risks }\end{array}$ & $\begin{array}{l}\text { Information } \\
\text { on the } \\
\text { Environment }\end{array}$ & $\begin{array}{l}\text { Information } \\
\text { on Personnel }\end{array}$ \\
\hline $\begin{array}{l}\text { The process of } \\
\text { updating the territorial } \\
\text { information system, } \\
\text { the total quality } \\
\text { project, the safety } \\
\text { chart and the service } \\
\text { chart has been started } \\
\text { There is also an } \\
\text { ongoing school } \\
\text { communication } \\
\text { initiative meant to } \\
\text { make aware of the } \\
\text { correct and sustainable } \\
\text { use of the water } \\
\text { supply. } \\
\text { Furthermore, the } \\
\text { company has adhered } \\
\text { to the school-work } \\
\text { alternation process } \\
\text { offered by } \\
\text { Confeservizi and } \\
\text { USR. }\end{array}$ & $\begin{array}{l}\text { The Salerno Sistemi } \\
\text { S.p.A. management } \\
\text { board, in } 2011 \text { has } \\
\text { approved a partnership } \\
\text { with Salerno Energia } \\
\text { Holding S.p.A. the } \\
\text { company does not own } \\
\text { any shares of parent } \\
\text { companies, neither has } \\
\text { it provided for the } \\
\text { purchase of such } \\
\text { shares. }\end{array}$ & $\begin{array}{l}\text { In } 2013 \text { an } \\
\text { arbitration } \\
\text { judgment was } \\
\text { issued in favor of } \\
\text { Salerno Sistemi } \\
\text { undertaken by } \\
\text { S.I.I.S. in regards } \\
\text { to the dispute } \\
\text { regarding the } \\
\text { sewerage and } \\
\text { purification } \\
\text { costs. }\end{array}$ & $\begin{array}{l}\text { A financial plan for the } \\
\text { years 2013-2016 } \\
\text { containing strategies for } \\
\text { targets achievement is } \\
\text { planned for } 2013 . \\
\text { Furthermore, there is a } \\
\text { plan to reduce financial } \\
\text { costs relating to the } \\
\text { abatement of bank loans } \\
\text { following the natural } \\
\text { reimbursement of the } \\
\text { installments on due dates. } \\
\text { In } 2015 \text { the two } \\
\text { mortgages with Banca } \\
\text { della Campania will be } \\
\text { extinguished. At last, } \\
\text { starting from } 2014 \text { there } \\
\text { will be a } \\
\text { liquidity-providing } \\
\text { operation consisting in } \\
\text { payment of a security } \\
\text { deposit from final users. }\end{array}$ & $\begin{array}{l}\text { The } \\
\text { administrators } \\
\text { affirm that in the } \\
\text { near future the } \\
\text { company will } \\
\text { not hold any risk } \\
\text { factors that } \\
\text { might } \\
\text { compromise its } \\
\text { existence. }\end{array}$ & - & $\begin{array}{l}\text { Salerno } \\
\text { Sistemi is } \\
\text { reorganizing } \\
\text { its personnel } \\
\text { so as to } \\
\text { reduce costs. }\end{array}$ \\
\hline
\end{tabular}

Table 7. Management report for Consac S.P.A. (year 2013): contents

\begin{tabular}{|c|c|c|c|c|c|c|}
\hline $\begin{array}{c}\text { Research and } \\
\text { development } \\
\text { activities }\end{array}$ & $\begin{array}{c}\text { Relationships with } \\
\text { subsidiaries, associated } \\
\text { companies, parent } \\
\text { companies and } \\
\text { companies controlled by } \\
\text { them }\end{array}$ & $\begin{array}{l}\text { Significant } \\
\text { events } \\
\text { occurred } \\
\text { after year } \\
\text { end closing }\end{array}$ & Business Outlook & $\begin{array}{l}\text { Information on } \\
\text { company } \\
\text { management } \\
\text { and financial } \\
\text { risks }\end{array}$ & $\begin{array}{l}\text { Information on the } \\
\text { Environment }\end{array}$ & $\begin{array}{l}\text { Information } \\
\text { on Personnel }\end{array}$ \\
\hline- & - & - & $\begin{array}{l}\text { There are provisions to collect } \\
\text { relevant sums of money for } \\
\text { invoices to be issued for the } \\
\text { years } 2014-2015 \text {, for service } \\
\text { supply contracts that benefit } \\
\text { from resident fees without } \\
\text { having a right to them. In } 2014 \\
\text { the forecast leads to a negative } \\
\text { balance, due to AEEGSI's } \\
\text { definition of a security } \\
\text { deposit. } \\
\text { Furthermore, a "water bonus" } \\
\text { will be launched for lower } \\
\text { income classes that will allow } \\
\text { them to get a part of the water } \\
\text { supply at zero charge. }\end{array}$ & $\begin{array}{l}\text { The request for } \\
\text { funding within } \\
\text { the procedure } \\
\text { for acceleration } \\
\text { of expenditures } \\
\text { was rejected by } \\
\text { the Region. }\end{array}$ & $\begin{array}{l}\text { The drinking water } \\
\text { sector presents some } \\
\text { widespread plant } \\
\text { obsolescence which } \\
\text { entail situations of } \\
\text { risk that are } \\
\text { fortunately very few. } \\
\text { The depuration and } \\
\text { sewerage sectors } \\
\text { require considerable } \\
\text { investments. }\end{array}$ & - \\
\hline
\end{tabular}


Table 8. Management report for Evi S.P.A. (year 2013): contents

\begin{tabular}{|c|c|c|c|c|c|c|}
\hline $\begin{array}{c}\text { Research and } \\
\text { development } \\
\text { activities }\end{array}$ & $\begin{array}{l}\text { Relationships with } \\
\text { subsidiaries, associated } \\
\text { companies, parent } \\
\text { companies and } \\
\text { companies controlled by } \\
\text { them }\end{array}$ & $\begin{array}{l}\text { Significant events } \\
\text { occurred after year } \\
\text { end closing }\end{array}$ & $\begin{array}{l}\text { Business } \\
\text { Outlook }\end{array}$ & $\begin{array}{l}\text { Information on } \\
\text { company } \\
\text { management and } \\
\text { financial risks }\end{array}$ & $\begin{array}{l}\text { Information on } \\
\text { the Environment }\end{array}$ & $\begin{array}{c}\text { Information on } \\
\text { Personnel }\end{array}$ \\
\hline- & - & $\begin{array}{l}\text { Resolution n. } 4 \text { of } \\
21.01 .2014 \text { of the } \\
\text { consociate Cisi, } \\
\text { provides the } \\
\text { possibility to reverse } \\
\text { the liquidation } \\
\text { process of the } \\
\text { company and to gain } \\
\text { access to the credit } \\
\text { market, so as to } \\
\text { being able to plan } \\
\text { the structural } \\
\text { investments aimed } \\
\text { to improve the } \\
\text { Island's water } \\
\text { distribution service } \\
\text { in relation to } \\
\text { sewerage and } \\
\text { depuration services. }\end{array}$ & $\begin{array}{l}\text { The company is } \\
\text { in liquidation } \\
\text { even though } \\
\text { there are good } \\
\text { financial } \\
\text { rebalancing } \\
\text { prospects and } \\
\text { effective } \\
\text { expense } \\
\text { containing } \\
\text { activities on. }\end{array}$ & - & $\begin{array}{c}\text { There have been } \\
\text { no environmental } \\
\text { damages. }\end{array}$ & $\begin{array}{l}\text { No work fatalities or } \\
\text { accidents have } \\
\text { occurred. No claims } \\
\text { for work related } \\
\text { diseases or mobbing } \\
\text { were filed for } \\
\text { employees or } \\
\text { ex-employees. }\end{array}$ \\
\hline
\end{tabular}

Table 9. Management report for Gori S.P.A. (year 2013): contents

\begin{tabular}{|c|c|c|c|c|c|c|}
\hline $\begin{array}{c}\text { Research and } \\
\text { development } \\
\text { activities }\end{array}$ & $\begin{array}{l}\text { relationships with subsidiaries, } \\
\text { associated companies, parent } \\
\text { companies and companies } \\
\text { controlled by them }\end{array}$ & $\begin{array}{l}\text { Significant events occurred } \\
\text { after year end closing }\end{array}$ & $\begin{array}{l}\text { Business } \\
\text { Outlook }\end{array}$ & $\begin{array}{l}\text { Information on } \\
\text { company } \\
\text { management and } \\
\text { financial risks } \\
\end{array}$ & $\begin{array}{l}\text { Information } \\
\text { on the } \\
\text { Environment }\end{array}$ & $\begin{array}{l}\text { Information on } \\
\text { Personnel }\end{array}$ \\
\hline $\begin{array}{l}\text { There are } \\
\text { innovations up } \\
\text { for information } \\
\text { systems, both } \\
\text { relating } \\
\text { to new } \\
\text { technologies } \\
\text { and } \\
\text { implementation } \\
\text { of new } \\
\text { functions }\end{array}$ & $\begin{array}{l}\text { The company carried out } \\
\text { intercompany operations with } \\
\text { consociates Ente d'Ambito and } \\
\text { Acea Group companies; such } \\
\text { operations have been carried } \\
\text { out under regular market } \\
\text { conditions. GORI is a } \\
\text { subsidiary to both Ente } \\
\text { d'Ambito Sarnese Vesuviano } \\
\text { and Sarnese Vesuviano srl. }\end{array}$ & $\begin{array}{c}\text { Banca Intesa San Paolo spa } \\
\text { Has approved the operation } \\
\text { to modify the funding } \\
\text { contract for } 40 \text { Millions in } \\
\text { multiannual loan. On } \\
\text { 17.01.2014 the company } \\
\text { GEST.I.RE srl was } \\
\text { established with GORI as } \\
\text { the sole shareholder in } \\
\text { order to manage the } \\
\text { regional activity. }\end{array}$ & - & $\begin{array}{l}\text { Gori is running a } \\
\text { few risks: } \\
\text { outstanding } \\
\text { credit toward } \\
\text { customer and } \\
\text { financial debt. }\end{array}$ & - & $\begin{array}{l}\text { Managing factors are } \\
\text { keeping being } \\
\text { monitored in order to } \\
\text { contain personnel } \\
\text { costs. Gori } \\
\text { cooperates with } \\
\text { Universities by } \\
\text { offering internship } \\
\text { and training. }\end{array}$ \\
\hline
\end{tabular}

Table 10. Management report for Asis S.P.A. (year 2013): contents

\begin{tabular}{|c|c|c|c|c|c|c|}
\hline $\begin{array}{c}\text { Research and } \\
\text { development } \\
\text { activities }\end{array}$ & $\begin{array}{c}\text { relationships with } \\
\text { subsidiaries, associated } \\
\text { companies, parent } \\
\text { companies and companies } \\
\text { controlled by them }\end{array}$ & $\begin{array}{l}\text { Significant events } \\
\text { occurred after } \\
\text { year end closing }\end{array}$ & $\begin{array}{c}\text { Business } \\
\text { Outlook }\end{array}$ & $\begin{array}{l}\text { Information on company } \\
\text { management and financial risks }\end{array}$ & $\begin{array}{l}\text { Information on } \\
\text { the Environment }\end{array}$ & $\begin{array}{c}\text { Information on } \\
\text { Personnel }\end{array}$ \\
\hline - & - & $\begin{array}{l}\text { There are not } \\
\text { significant facts } \\
\text { affecting the } \\
\text { business. }\end{array}$ & - & $\begin{array}{l}\text { No warnings on risk, since the } \\
\text { company has adopted some } \\
\text { caution criteria and has not started } \\
\text { any speculative operations. }\end{array}$ & - & - \\
\hline
\end{tabular}


Table 11. Reference model

\begin{tabular}{|c|c|c|}
\hline Information on Financial Risks & Personnel Information & Information on the Environment \\
\hline $\begin{array}{l}\text { Market risk; } \\
\text { Pricing risk; } \\
\text { Currency risk; } \\
\text { Interest rate risk; } \\
\text { Credit risk; } \\
\text { Liquidity risk, } \\
\text { Risk related to financial } \\
\text { trends variations }\end{array}$ & $\begin{array}{l}\text { Education and refresh training activities that } \\
\text { were planned and carried out; } \\
\text { Chosen remuneration policies and career } \\
\text { systems adopted; } \\
\text { Initiatives meant to promote equal } \\
\text { opportunities; } \\
\text { Creation of crèche facilities; } \\
\text { Workplace conditions; } \\
\text { Activities meant to generally promote the role } \\
\text { of human resources within the company; } \\
\text { Industrial and union relationships; } \\
\text { Presence of self-evaluation systems. }\end{array}$ & $\begin{array}{l}\text { Identification of environmental costs and waste; } \\
\text { Evaluation of opportunities for investments in } \\
\text { environmental friendly technologies; } \\
\text { Evaluation of the level of care taken in territory } \\
\text { valorization; } \\
\text { identification of critical elements linked to one's own } \\
\text { activity and of the action meant for environmental } \\
\text { improvement; } \\
\text { Creation of a monitoring network that allows an } \\
\text { environmental management system development } \\
\text { (ISO14000 od EMAS); } \\
\text { Development of efficient environmental communication } \\
\text { tools for the population and public administration }\end{array}$ \\
\hline
\end{tabular}

\section{References}

Aa, V. (2008). Società commerciali. Milano: Ipsoa Francis Lefebvre.

Adinolfi, P. (2005). L'aziendalizzazione delle pubbliche amministrazioni: Teoria e pratica a confront. Azienda Pubblica, 1. http://dx.doi.org/10.2139/2062111

Anselmi, L. (2003). Percorsi aziendali per le pubbliche amministrazioni. Torino: Giappichelli.

Azzolini, I., De, S. M., \& Guidi, M. (1996). La trasformazione delle aziende per la gestione dei servizi pubblici locali. Rimini: Maggioli.

Bagnoli, C. (2003). La relazione sulla gestione: Un'analisi empirica. Rivista dei dottori commercialisti, 5.

Bazzani, R. (2003). Quale valutazione per le aziende del settore idrico? Azienda Pubblica, 1-2.

Bellante, F. (2000). Il sistema dei servizi pubblici. Le dinamiche evolutive verso nuovi profili di competitività. Padova: Cedam.

Borgonovi, E. (2004). Principi e sistemi aziendali per le amministrazioni pubbliche (4th ed.). Milano: Egea.

Bratta, S. M. (2004). La valorizzazione dei servizi pubblici locali. Modalità gestionali, assetti societari e tecniche utilizzabili, Azienda Pubblica, 1.

Calvosa, F. M. (2007). La governance degli enti locali nella gestione dei servizi pubblici. Rubbettino: Soveria Mannelli.

Capaldo, P. (1998). Reddito, capitale e bilancio d'esercizio. Milano: Giuffrè.

Caratozzolo, M. (2006). Il Bilancio d'esercizio. Milano: Giuffrè.

Cassese, S. (2001). I rapporti tra Stato ed economia all'inizio del XXI secolo. Giornale Diritto Amministrativo.

Catturi, G. (2006). La redazione del bilancio d'esercizio. Padova: Cedam.

Comite, U. (2008). Principi aziendali e utilizzo della contabilità ambientale. Strumenti di lavoro e calcolo degli indicatori. Aracne.

Conti, F. (2000). Servizi pubblici e infrastrutture urbane in Italia fra Ottocento e Novecento: Un bilancio degli studi, Il Comune democratico. Riccardo Dalle Mole e l'esperienza delle giunte bloccarde nel Veneto giolittiano (1900-1914). Marsilio: Venezia.

Cristofoli, D. (2004). La riforma dei servizi pubblici locali tra accettazione e compromesso, Azienda Pubblica, 1.

D'Alessio, L. (1992). La gestione delle aziende pubbliche: Problemi di programmazione, controllo $e$ coordinamento. Torino: Giappichelli.

De, F. O. (2007). Il valore delle informazioni quale elemento essenziale della relazione sulla gestione ex art. 2428 cc. Esperienze d'impresa, 2.

De, S. M. (2007). La relazione sulla gestione. Ruolo formativo e contenuto della stessa, Rivista Italiana di Ragioneria e di Economia Aziendale, 9-10. 
Dezzani, F., Pisoni, P., \& Puddu, L. (1996). Il bilancio e la IV Direttiva CEE. Milano: Giuffrè.

Di, G. M. E. (2008). Il bilancio sociale e il modulo aziendale etico. Milano: Giuffrè.

Elefanti, M. (2006). L'evoluzione delle imprese pubbliche locali. Il caso Enìa. Bologna: Il Mulino.

Farneti, F. (2004). Il progressivo affermarsi del principio di accountability degli enti locali. Milano: Angeli.

Farneti, G. (2000). Il bilancio dell'ente locale. Torino: Giappichelli.

Farneti, G. (2004). Ragioneria pubblica. Il "nuovo" sistema informativo delle aziende pubbliche. Milano: Angeli.

Formisano, V., Russo, G., Celenza, D., \& Lombardi, R. (2012). L'informativa esterna delle imprese di servizi e le novità introdotte nell'art. 2428 del codice civile. Alcune evidenze empiriche. Rivista Italiana di Ragioneria e di Economia Aziendale, 7-8.

Giovanelli, L. (2000). Modelli contabili e di bilancio in uno stato che cambia. Milano: Giuffrè.

Giunta, F., \& Pisani, M. (2008). Il bilancio. Milano: Apogeo.

Giuntini, A. (2000). La modernizzazione delle infrastrutture e dei servizi urbani in Italia. Temi, risultati e obiettivi della ricerca storica. In Lacaita C. G. (Ed.), Scienza tecnica e modernizzazione in Italia fra Otto e Novecento. Milano: Angeli.

Gray, R. H., Owen, D., \& Adams, C. (1996). Accounting and accountability: Changes and challenges in Corporate social and environmental reporting. Prentice Hall Europe, Hemel Hempstead, Hertfordshire.

Grossi, G. (2006). La corporate governante delle aziende di servizio pubblico locale quotate in Borsa. Rivista Italiana di Ragioneria e di Economia Aziendale, 7-8.

Jannelli, R. (2006). Governance e misurazione delle performance nell'Azienda Pubblica. Un possibile approccio. Roma: Aracne.

Kao, R. (1995). Enterpreneurship: A wealth Creation and Value Adding Process. Singapore: Prentice Hall.

Liguori, F. (2007). I servizi pubblici locali. Torino: Giappichelli.

Marchini, P. L., \& Tibiletti, V. (2004). Bilancio sociale e valori d'impresa. Parma, Monte Università Parma.

Marrelli, M., Padovano, F., \& Rizzo, I. (2007). Servizi pubblici. Nuove tendenze nella regolamentazione, nella produzione e nel finanziamento. Milano: Angeli.

Mele, R. (1993). Strategie e politiche di marketing delle imprese di pubblici servizi. Padova: Cedam.

Metallo, G., Ricci, P., \& Migliccio, G. (2005). Aziende e sindacati: profili etici. Elementi teorici e tracce esperenziali. Torino: Giappichelli.

Molteni, M. (2000). Bilancio e strategia. L'annual report come occasione per comunicare strategia e risultati a tutto campo. Milano: Egea.

Mulazzani, M. (2006). Economia delle aziende e delle amministrazioni pubbliche. Padova: Cedam.

Mulazzani, M., \& Pozzoli, S. (2005). Le aziende dei servizi pubblici locali. Rimini: Maggioli.

Mussari, R. (1999). La valutazione dei programmi nelle aziende pubbliche. Torino: Giappichelli.

Ohmae, K. (1999). The borderless World. Power and Strategy in the Interlinked Economy. New York: Harper.

OIC (Organismo Italiano di Contabilità). (2006). Principi contabili. Le informazioni sugli strumenti finanziari da includere nella nota integrativa e nelle relazione sulla gestione. Milano: Giuffrè.

Oliva, N. (2008). L'informativa extracontabile: Rischi, ambiente, personale, in Antonelli V., D'Alessio R., Summa Bilancio. Milano: Il Sole 24 Ore.

Onida, P. (2005 ristampa). Economia d'azienda. Torino: Utet.

Padovani, E. (2004). Il governo dei servizi pubblici locali in outsourcing. Il controllo dell'efficacia. Milano: Franco Angeli.

Palma, A. (2003). Il bilancio di esercizio. Milano: Giuffrè.

Pavan, A., \& Reginato, E. (2004). Programmazione e controllo nello Stato e nelle altre amministrazioni pubbliche. Milano: Giuffrè.

Petrolati, P. (2007). L'adeguamento della normativa italiana alle direttive contabili comunitarie: La Relazione 
sulla gestione. Impatti e scenari, Quaderni monografici Rirea, n. 56.

Pezzani, F. (2003). L'accountability delle amministrazioni pubbliche. Milano: Egea.

Pozzoli, S. (2004). Quale "contabilità" per gli enti locali. Azienditalia, 4.

Puddu, L. (2001). Ragioneria pubblica: Il bilancio degli enti locali. Milano: Giuffrè.

Pulejo, L. (2005). Comunicazione e accountability nell'azienda Comune. Giappichelli: Torino.

Ranghieri, F., \& Sammarco, G. (1997), Ecobilanci, in aumento e sempre più esaurienti. Il Sole 24 Ore, 24 November.

Rebora, G. (1999). La valutazione dei risultati nelle amministrazioni pubbliche: Proposte operative e di metodo. Milano: Guerini Studio.

Ricci, P. (2005). Enti strumentali regionali e loro accountability. Il caso Campania. Milano: Angeli.

Ricci, P. (2007). Introduzione all'economia aziendale. Milano: Giuffrè.

Silvi, R. (2006). Analisi di bilancio: La prospettiva manageriale. Milano: McGraw-Hill.

Sorace, D. (2000). Diritto delle amministrazioni pubbliche. Una introduzione. Bologna: Il Mulino.

Staffico, L. (2002). L'informazione aziendale sull'ambiente. Rivista dei dottori commercialisti, 1.

Steccolini, I. (2004). Accountability e sistemi informativi negli enti locali. Torino: Giappichelli.

Terzani, S. (2000). Il sistema dei bilanci. Milano: Angeli.

Zanda, G. (2007). Il bilancio delle società. Lineamenti teorici e modelli di redazione. Torino: Giappichelli.

\section{Notes}

Note 1. For more information please check the following: Giunta, Pisani (2008, pp. 347-382); De Sarno (2007, pp. 458-466); Petrolati (2008, pp. 6-58).

Note 2. C. Bagnoli, La relazione sulla gestione: Un'analisi empirica, in Rivista dei dottori commercialisti (Accountants Magazine), Giuffré, Milano, n. 5/2003, pagg. 987 e ss. Please also see F. Dezzani, P. Pisoni, L. Puddu, Il bilancio e la IV Direttiva CEE, Giuffrè, Milano, 1996 e A. PALMA, Il bilancio di esercizio, Giuffrè, Milano, 2003.

Note 3. P. Capaldo, Reddito, capitale e bilancio d'esercizio, Giuffrè, Milano, 1998, p. 307 e ss.

Note 4. For more information on this subject, please see: Ricci (2005); Steccolini (2004); Farneti (2004); Pezzani (2003); Pulejo (2005); Mulazzani (2006); Comite (2008).

Note 5. In Italy Lgs. D. 626/94 has introduced risk assessment as a requirement for employers as well as a Service of Protection and Prevention, for which RSPP is responsible. Risk assessment is, therefore, a process aimed to detect risks and, later, all the prevention and protection measures meant to reduce the probability of damages stemming from potential professional disease and accidents.

Note 6. The concept of sustainable development was drawn up in 1987 by the world Commission on environment and development. (Brundtland Report, United Nations, 1987). After the UN conference on environment and development held in in Rio de Janeiro on 14 June 1992), sustainable development became an objective declared by financial and environmental policies in many countries and by international agreements on environmental matters. According to the definition given in the Brundtland report, in order for development to be sustainable, it must meet the needs of the present generations without compromising the capacity of future generations to meet their own needs.

Note 7. Alto Calore Servizi (ACS), was estabilished on 13/3/2003 from the conversion of Consorzio Interprovinciale Alto Calore in two separate Inc.s under full public ownership, called respectively: "Alto Calore Servizi S.p.A." and "Alto Calore Patrimonio e Infrastrutture S.p.A." It is a joint-stock company, whose partners are 127 municipalities with a share capital allocated as follows: $66,62 \%$ to the Municipalities located in the province of Avellino; 22,72\% to the Municipalities located in the Province of Benevento; the remaining $10,66 \%$ to the Provincial Administration of Avellino. The company operates in the sector dealing with sewage, waste water treatment, drinking water collection and distribution. The total distribution network runs for over $4.500 \mathrm{~km}$, reaching a population of 450.000 .

Note 8. Ausino S.p.A. Servizi Idrici Integrati, in the past called Consorzio degli acquedotti dell'Ausino, has its 
offices in Cava de' Tirreni (SA). The company manages the water supply network servicing the Picentini Municipalities, low and high Irno Valley, Agro Nocerino Sarnese, Salerno, Cava de' Tirreni and the Amalfi coast. In conjunction with many associated Municipalities and with Ente d'Ambito Sele (ATO 4 Campania Region), has been managing, since 2001, the integrated water supply service in the territory belonging to the associated Municipalities. From then on, it has started an efficiency, efficacy and cost-effectiveness recovery program of the undertaken managements, operating in view of law n. 36 of 05.01.1994 (Galli Regulation).

Note 9. ABC Napoli Azienda speciale (was Arin S.p.A.) is today one of the largest water distribution managing companies in the South of Italy and it reaches a population of about 1.650 .000 between Naples and the provinces of Avellino, Benevento, Napoli and Caserta.

Note 10. L'ASIS Salernitana Reti e Impianti S.p.A. has its headquarters in Salerno and provides water services in 50 Municipalities. It manages a $500 \mathrm{~km}$ network and is currently the largest water providing authority in the Province of Salerno.

Note 11. Consac Gestioni Idriche S.p.A. as Local Authorities Consortium, later transformed in Special Consortium Company manages integrated water service in 48 Municipalities in the province of Salerno.

Note 12. Energia Verde Idrica (EVI), succeeded in 2000 to CISI1, is a joint-stock company operating in the Island of Ischia's territory, comprising a surface of $46,32 \mathrm{Km}$, serving a population of 56.763 residents, that increases in the summer to about 250.000 units. The distribution network is $405 \mathrm{Km}$ long. a 250.000 .

Note 13. GORI S.p.A. is the manager of the Integrated Water Service in the Optimum Territorial Context no. 3 of Campania and holds as its main objective to make efficient, effective and cost effective the management of the water supply. The company provides water distribution service in the Provinces of Salerno and Napoli, reaching about 500.000 users.

Note 14. Gesesa S.p.A., used to be Beneventana Servizi S.p.A.-it has been providing integrated water services since 1992 in the Samnium area. In 2000, Gesesa S.p.A. was the first company in the sector in Southern Italy to obtain the UNI EN ISO 9002 quality certification. It is able to design, build and maintain aqueducts, sewerage and purification networks.

Note 15. Salerno Sistemi, established on 25 February 1998, operates in the integrated water cycle. Today it is owned by the City Council of Salerno for $51 \%$ and by Società De Luca Group Italy S.p.a. for 49\%. In the integrated water cycle field, Salerno Sistemi is the service agent for the water supply for the city of Salerno, that is, it purchases the resource to be sold to third parties (mostly ASIS, AUSINO, and partially to Eniacqua Campania S.p.A.) or it acquires it from supply sources that are directly managed (Prepezzano spring) and makes it available to the final users' tap.

Note 16. See tables on pag. 8 e ss.

Note 17. See table on page 16.

\section{Copyrights}

Copyright for this article is retained by the author(s), with first publication rights granted to the journal.

This is an open-access article distributed under the terms and conditions of the Creative Commons Attribution license (http://creativecommons.org/licenses/by/3.0/). 